\title{
Designing for adaptation: the school as socio-spatial assemblage
}

\author{
Kim Dovey, Kenn Fisher
}

\author{
Faculty of Architecture, Building \& Planning, \\ University of Melbourne, Parkville, 3010 Victoria, \\ Australia (Author's email address: dovey@unimelb. \\ edu.au)
}

Over the last century we have seen a slow transformation of the architecture of school classrooms in response to changing pedagogical theory and practice. A shift from teacher-centred to student-centred learning is accompanied by the move towards a more 'open' plan with new spatial types, interconnections and modes of adaptation. This paper seeks to understand this linkage of plans to pedagogies in the case of the middle school. Using an analytic framework of assemblage theory, clusters of learning spaces from a range of recent innovative school plans are analysed in terms of capacity for socio-spatial interconnection and adaptation. Five primary plan types are identified, ranging from the traditional classroom through various degrees of convertibility to permanently open plans. Patterns of spatial structure and segmentarity emerge to enable new forms of teaching and learning on the one hand, but also to camouflage a conservative pedagogy on the other. If traditional classrooms with their corridors and doors can be understood in terms of Foucaultian disciplinary technology, the new learning clusters suggest a use of Deleuzian social theory to understand an architecture of connectivity and flow. Through an analysis that is intended to reveal rather than eliminate ambiguities, architectural capacities for 'convertibility' from one pedagogy to another are distinguished from properties of 'agility' or 'fluidity' that enable continuous adaptation between learning activities. We find that the most popular types have high levels of convertibility and reveal conflicting desires for both discipline and empowerment. We also suggest that the most open of plans, while cheaper to build, are not the most agile or fluid.

\section{Introduction}

The design of learning environments at every level from primary to tertiary is undergoing a major transformation involving the proliferation of new learning spaces that are variously termed learning 'streets' or 'commons', 'meeting' spaces and 'outdoor learning' areas together with complex new interrelationships and overlaps between them. ${ }^{1}$ Such changes are largely driven by long-standing changes in pedagogical theory and practice that may be broadly described as a recognition of both formal and informal learning and a move from teacher-centred to student-centred learning. The traditional classroom is a product of a teacher-centred pedagogy, framing a hierarchical relationship between teacher and students whilst closing out other activities and distractions. It is also a form of what Foucault terms a disciplinary technology where the gaze of authority works to produce a normalised and disciplined subject. ${ }^{2}$ It has long been clear that student- 
centred pedagogies are seriously constrained by traditional classrooms. What is not so clear is how new forms of open school environments are matched to the new pedagogies. The primary goal of this paper is critically to analyse a range of recent celebrated middle-school plans within such a theoretical and pedagogical framework.

This transformation in school design has a century-long history that we cannot recount in detail here. The nineteenth-century school was based on a monitorial model with large groups being taught by one teacher at the front supported by a number of monitors who drilled smaller groups on the material set by the lead teacher (Burke \& Grosvenor, 2008). By the late nineteenth century this large space became segmented into what remains the standard classroom type with classes of 25-40 students. ${ }^{3}$ From the early twentieth century Dewey argued for a more student-centred model of learning highlighting the importance of social context, student interaction and play. ${ }^{4} \mathrm{~A}$ range of architectural innovation commenced as some schools became more connected to the outdoors and 'hands on' learning spaces such as laboratories, studios, workshops and gymnasia were incorporated. The trend towards 'open-air schools' developed through the educational ideas of Steiner and Montessori and was especially strong for early childhood.

Following the Second World War, the modernist movement in architecture was deployed in a rapid increase in school construction programmes for expanding student numbers-the mass-production of traditional classrooms most of which still operate today. At the same time there was consider- able architectural innovation linked to new pedagogies through the work of Scharoun, van Eyck and Hertzberger and others. ${ }^{5}$ In the 1970 s the so called 'open-plan' school began to proliferate in the developed world, a move that was largely abandoned by the 1980s when many such open plans became segmented into traditional classroom cells. While there were many reasons for this failure (including acoustics) it is clear that such open plans often confused flexibility with openness and were poorly matched to new learning practices. In the new century we are seeing a substantial re-emergence of studentcentred pedagogy in all educational sectors, geared also to communications technologies and information flows that are difficult to optimise in the traditional classroom. A new round of architectural innovation has emerged globally with the overt goal to enable better such pedagogies. Instead of simply 'open' plans we are seeing assemblages of different spaces grouped in clusters with meeting rooms, learning commons and traditional classrooms in a myriad of new arrangements. Our key research question here is focused on this emergence of new plan types. How does architecture respond to changing pedagogy and how are underlying issues of power, control and discipline played out? Questions about the success of such pedagogies or plan types in terms of learning outcomes are important but such research lies beyond the scope of this paper.

A typological framework is proposed for analysing both pedagogical practices and the typical plans that have emerged to accommodate them. We suggest a model for understanding the connections between architecture and pedagogy, and apply it to the 
analysis of a sample of middle-school plans recognised as innovative in responding to new pedagogies. To contain the complexity we have focused on middle schools and on the primary teaching 'clusters' within those schools. The middle school, incorporating the ages of about 12-15 years, is recognised as a time when students are undergoing significant transformative experiences: moving into adolescence with related puberty issues, moving from primary school to secondary and taking increased responsibility for their learning. There is much at stake in this age group, as Eccles et al. argue: 'It is at this stage that many children who were doing well at and enjoying school begin to lose interest and develop patterns of behaviour inimical to successful school completion'. ${ }^{6}$ Middle schools paradoxically emerge as places where students may need supervision and control but also where there is great potential for new pedagogies to open pathways of student-centred learning.

\section{New pedagogies}

The evolution of pedagogical theory that drives this transformation can be very simply framed as three stages: behaviourist, cognitivist and constructivist. Behaviourist approaches are based on the stimulusresponse psychology of Pavlov and Skinner linked to a didactic teacher-centred pedagogy, and a 'bells and cells' model of school planning and design where time and space are clearly segmented. Cognitivist approaches emerged through the works of psychologists such as Bruner and Piaget who argued for an approach directed at moving from lower-order to higher-order thinking through a hierarchy of activities-remembering, understanding, applying, analysing, evaluating and synthesisingeach associated with a range of learning spaces. ${ }^{7}$ Constructivism emerged in the 1970s, largely based on the much earlier work of Vygotski who argued that remembering and application of knowledge had to be situated in the student's lived world in order to become authentic learning. In other words, students 'construct' their own meanings and they do so in a social context. ${ }^{8}$ In this view learning is first interpersonal or social, and only then becomes embodied: the higher functions of learning originate as social relationships. The learning environment is seen as a zone (at once social, spatial and informational) within which existing skills and knowledge can be connected with those that might be learned next. The school environment in this sense can be seen as 'scaffolding': a temporary framework that enables the social construction of knowledge to take place and then be removed as students become autonomous learners. ${ }^{9}$ It is central to constructivist learning theory that genuine understanding is related to the extent to which the student can interact with both adults and peers in a flexible and open-ended manner within the framework of a duty of care by the teacher.

While many of the experiments with open planning from the 1970s were perceived to fail, constructivist pedagogies have since been increasingly adopted by educational institutions and ministries globally, generally under the rubric of 'studentcentred learning'. The demand for a more pedagogically supportive school architecture has led to the emergence of organisations (in the English-speaking world) such as the Council for Educational Facility 
Planners International (CEFPI), Design Share: Designing for the Future of Learning, and the British Council for School Environments (BCSE) devoted to this transformation. It is from these organisations we draw our sample of plans.

In order to analyse the relationships to spatial form and structure, we have developed a list of six key teaching/learning practices based in constructivist pedagogies. This typology is summarised in Table 1 and covers a continuum of group size from large group presentations, through four kinds of interactive activity in smaller groups, to the reflective activities of the single student (Table 1). These are not separate types so much as a simplified framework for understanding and analysis. This typology is based in pedagogical theory and can be linked to a number of such typologies that have been developed in the literature. ${ }^{10}$ The listing of the typology in this form is not intended as reductionist or mechanical: these categories are tools for analysis. In an everyday situation these different pedagogical practices morph rapidly and frequently into each other as groups form and break up with different activities over the day. The different types are richly interconnected both in space and over time as groups segment and amalgamate, as students and staff move between different activities. Didactic teaching (as presentation) remains part of this mixture but is reduced to a small portion of the total time.

\section{New plans and spatial types}

We now analyse an internationally sourced sample of 59 notable and award-winning middle schools drawn from the three organisations listed earlier and that were designed to engage with pedagogical change. The largest cohort (41 plans) is from the awards programme for new school design as published by Design Share: Designing for the Future of Learning. This is an organisation that showcases: 'examples of innovation that remind us why school buildings and campuses exist in the first place: learning! More importantly, we focus on how we design for the ever-changing future of learning and larger community connections'. ${ }^{11}$ The second source (10 plans) is from the Australian awards programme of the Council of Educational Facility Planners International (CEFPI) an organisation with an agenda of 'promoting best practices in creative school planning'. ${ }^{12}$ A further cohort (8 plans) has been derived from contacts within the British Council for School Environments, a more recent organisation devoted to 'new thinking about schools and learning environment design'. ${ }^{13}$ The total sample has a bias towards the English-speaking world but includes examples from Japan, Singapore, the Netherlands, China, India and Norway. This comprises a total database of 59 middle school plans constructed over the past decade and covering a broad range of attempts to engage with new pedagogies through innovative architecture.

These plans are replete with spatial categories such as 'general learning area', 'learning commons', 'learning street', 'open learning', 'lounge', 'collaborative learning', 'studio', 'meeting', 'activity area' and 'breakout', each of which can mean many things. While such discourse can usefully indicate an intention, our analysis focuses on the form and structure of the architectural space-including the adaptations that it enables or constrains. Rather than simply reading these categories off the plans 
Table 1. A typology of student-centred pedagogies.

\begin{tabular}{|c|c|}
\hline $\begin{array}{l}\text { PRESENTATION } \\
25-150 \text { students }\end{array}$ & $\begin{array}{l}\text { Students or teachers present to a largely passive group. } \\
\text { Group size may vary from one class cohort to a full form } \\
\text { or year. Such activities facilitate efficient communication } \\
\text { of information. }\end{array}$ \\
\hline $\begin{array}{l}\text { LARGE INTERACTIVE } \\
\text { 25-75 students }\end{array}$ & $\begin{array}{l}\text { Activities that move seamlessly from large to small group } \\
\text { and back; often organized in sub-groups of } 4-6 \text { that can } \\
\text { be subdivided again into } 2 \text { s or } 3 \mathrm{~s} \text {. Facilitates peer-to- } \\
\text { peer learning and team teaching. }\end{array}$ \\
\hline $\begin{array}{l}\text { MEDIUM INTERACTIVE } \\
10-25 \text { students }\end{array}$ & $\begin{array}{l}\text { Activities with a similar flow of movement to the above, } \\
\text { but with a smaller group size and generally one teacher. }\end{array}$ \\
\hline $\begin{array}{l}\text { CREATIVE INTERACTIVE } \\
\text { 10-25 students }\end{array}$ & $\begin{array}{l}\text { Interactive activities but with an emphasis on hands-on } \\
\text { learning in addition to pens and keyboards, plus access } \\
\text { to a range of resources that may include art materials, } \\
\text { wet areas, laboratory or outdoors. }\end{array}$ \\
\hline $\begin{array}{l}\text { SMALL INTERACTIVE } \\
2-5 \text { students }\end{array}$ & $\begin{array}{l}\text { The 'breakout' model of problem-based and peer-to-peer } \\
\text { learning with small autonomous groups that can disperse } \\
\text { and take responsibility for their learning. }\end{array}$ \\
\hline $\begin{array}{l}\text { REFLECTION } \\
1 \text { student }\end{array}$ & $\begin{array}{l}\text { Singular activities that include reading, writing or hands- } \\
\text { on research to meet learning objectives. }\end{array}$ \\
\hline
\end{tabular}


we have analysed the plans to develop a typology of spatial types. Our focus concentrates on the primary learning clusters of each school, excluding those facilities that are shared with the larger school community. The key questions are: first, how have these spatial clusters been segmented into spatial cat- egories or place types; and second, how have such categories or types been assembled in support of new pedagogies? We have classified the different spatial types found within the learning clusters into six primary categories as described in Table 2 . These spatial types begin with the traditional classroom

Table 2. A typology of learning spaces.

\begin{tabular}{|c|c|}
\hline CLASSROOM & $\begin{array}{l}\text { A traditional closed learning space of about } 40-60 \text { sq metres for } 20- \\
30 \text { students. If learning spaces are fully 'closeable' to this size with } \\
\text { flexible walls then they are classified as classrooms. }\end{array}$ \\
\hline COMMONS & $\begin{array}{l}\text { A learning space of greater than about } 40 \text { sq metres that cannot be } \\
\text { fully closed into a } 25 \text { student classrooms (or smaller) and is not the } \\
\text { major access route to any other commons or classroom, hence } \\
\text { protected from major through traffic. }\end{array}$ \\
\hline STREETSPACE & $\begin{array}{l}\text { An open learning space over about } 3 \text { metres width (allowing activity } \\
+ \text { circulation) that cannot be closed into classrooms and is exposed } \\
\text { to major through traffic as the primary access space to other learning } \\
\text { spaces. }\end{array}$ \\
\hline $\begin{array}{l}\text { MEETING } \\
\text { AREA }\end{array}$ & $\begin{array}{l}\text { A small learning area of less than } 40 \text { square metres accommodating } \\
\text { groups of } 5 \text { to } 20 \text {. While such spaces may house seminars, the key } \\
\text { criterion is that they cannot house a traditional class size. }\end{array}$ \\
\hline $\begin{array}{c}\text { FIXED } \\
\text { FUNCTION }\end{array}$ & $\begin{array}{l}\text { Any learning space fitted for specialized use such as 'Arts', } \\
\text { 'Science', 'IT', 'Computers', 'Wet Area', 'Music', 'Drama', } \\
\text { 'Resources'. }\end{array}$ \\
\hline $\begin{array}{l}\text { OUTDOOR } \\
\text { LEARNING }\end{array}$ & $\begin{array}{l}\text { Any outdoor area defined on the plan as an integral part of the } \\
\text { learning cluster, generally labelled 'outdoor learning', 'outdoor room' } \\
\text { or 'learning court'. Simple access to the outdoors does not qualify. }\end{array}$ \\
\hline
\end{tabular}


but are extended to what we are calling the 'commons', 'streetspace', 'meeting', 'fixed function' and 'outdoor learning' (Table 2).

Such a typology simplifies a complex range of places; a more extensive typology may be more fine-tuned but the capacity to understand the clusters would decline. The six categories are rarely mutually exclusive and often overlap. Meeting areas and fixed functions can be an integral part of commons, streetspace and classrooms or they can be separated. Some spaces can be transformed from one type to another, a key issue to which we will return. The distinction we propose between 'streetspace' and 'commons' is salient because the existence or absence of through traffic enables and/or constrains a different range of learning activities with impacts on issues of privacy, group identity and the acoustic environment. We have designated an open-learning area as 'streetspace' when it also has a primary function as a thoroughfare. The loss of acoustic control strips the space of significant teaching and learning functions. In addition to this six-part typology we have also mapped two categories of ancillary space: corridors or access spaces too small for learning activities ( $<2$ metres) other than display; and 'staff only' areas.

\section{Complex adaptive assemblage}

We have thus far suggested typologies of 6 pedagogical practices and 6 spatial types. Each learning cluster is a set of spatial parts ('meeting', 'classrooms', 'commons', 'streetspace', 'outdoors' and 'fixed') that enable or constrain different teaching/ learning practices (presentation, interaction, retreat and so on). Before analysing these interconnections we first flag three key issues followed by a short theoretical excursion. First, we seek to map the potential rather than actual use of these spaces: to sketch the complex 'space of possibility' produced by the architecture. Second, the degree to which each space can adapt to different practices becomes crucial; the learning 'commons' and the 'outdoors' are the only spatial types that easily accommodate all learning practices from Table 1, while others such as 'meeting', 'streetspace' and 'fixed' spaces are geared to a narrower range. Third, the structure of interconnections between elements of each cluster (the ways they are assembled) will be crucial mediators of spatial flows from one practice to another. These three characteristics-complexity, adaptability, assemblage-mark these new learning clusters as complex adaptive assemblages.

We want to flag briefly two related theoretical frameworks that have driven the analysis and that draw upon these three key terms: complexity, adaptability and assemblage. The first of these is 'assemblage' theory, as developed particularly by DeLanda based on the book 'A Thousand Plateaus' by Deleuze and Guattari. ${ }^{14}$ The term 'assemblage' here is a translation of the french 'agencement' which is akin to an 'arrangement' or 'alignment': it suggests at once both dynamic process and a diagrammatic spatiality. Assemblage is a useful way of re-thinking theories of 'place' in terms of process, identity formation and becoming. ${ }^{15}$ An assemblage is a whole that is formed from the interconnectivity and flows between constituent parts-a sociospatial cluster of interconnections between parts wherein the identities and functions of both parts 
and wholes emerge from the flows between them. A learning cluster is not a thing or a collection of things, it is the assembled connections between them (at once social and spatial) that are crucial. Assemblage is at once verb and noun: it is the flows of life, people, materials and ideas that give the learning cluster its emergent potential. The dynamism of assemblage involves the ways territories and boundaries are inscribed and erased, the ways identities are formed, expressed and transformed. Territory is a stabilised assemblage, a zone of order, a sense of home that keeps chaos and difference at bay. ${ }^{16}$ Deterritorialisation is the movement by which territories are eroded as new assemblages are formed. Traditional classrooms are fixed territories while the spaces designed for new pedagogies are relatively deterritorialised.

The increasing levels of complexity, adaptability and self-organisation embodied in constructivist pedagogies suggest a second and complementary framework of complex adaptive systems theory which seeks to understand the dynamics of complex systems where the outcome of a system depends on unpredictable interactions between parts. This is work that grows out of a mixture of theories of cybernetics, chaos, complexity and resilience, much of it transferred from the study of natural systems. ${ }^{17}$ A complex system is one where the parts adapt to each other in relatively unpredictable ways, they self-organise. The detailed outcomes of such a system cannot be determined in advance but rather 'emerge' from practices of adaptation and self-organisation. ${ }^{18}$ Some key properties of complex adaptive systems include the diversity and redundancy of different parts such that each per- forms a multiplicity of functions where no single part is crucial to success and the system can adapt by moving forms, functions and flows around. The tendency to maximise efficiency of the systemoften the goal of formal planning — can lead to a loss of redundancy. As with assemblage theory, there is no easy way to define the 'system' as each learning cluster is an interactive part of further systems at higher scales: school, community, local government and state. The use of complex adaptive systems theory has been applied to learning environments but without the focus on spatial structure and assemblage that we deploy. ${ }^{19}$ While such work is often conducted within a framework of complex adaptive systems it does not imply the predictability or fixed outcomes of systematic control-indeed, the opposite. We suggest that 'complex adaptive assemblage' is a more accurate and useful label for the classroom clusters we have analysed. ${ }^{20}$

\section{Mapping learning clusters}

Our analysis of the plans involves understanding the degree to which each of the spatial types appears in the sample plans, and the forms or patterns of interconnectivity and interpenetration with adjacent spaces. To this end we have developed a method of diagramming each plan according to the presence of the spatial types and the degree of their segmentarity into closed or closeable teaching areas. Such an approach has important antecedents in architectural theory. The earliest is perhaps the analyses of March and Steadman showing how the work of even the best of architects has an underlying spatial structure or grammar. ${ }^{21}$ The spatial syntax analysis of Hillier and others is a means to under- 
stand the sociality of spatial structure. ${ }^{22}$ Such an approach relies largely upon the analysis of separated spatial segments and works best in detecting the socio-spatial genotypes of highly segmented space: such as the ways in which a traditional school reproduces traditional pedagogy. The spatial structure of a series of classrooms entered from a single corridor is identified with the architecture of discipline and with institutions of surveillance and control, linked to their cousins in the prison, asylum, office, hospital and so on. ${ }^{23}$ Another clear antecedent is that of Alexander and his colleagues in the development of a 'pattern language'. ${ }^{24}$ For Alexander a pattern is at once a set of socio-spatial forces and a formal diagram that resolves them. Whilst such design patterns are often seen as formulaic, Alexander's approach involves a multiplicity of fluid patterns and has some things in common with assemblage theory. ${ }^{25}$

To analyse the emerging plans we have developed a method of mapping that represents the range of spatial types together with segmentarity, interpenetration, connectivity and adaptability. We have developed a method to represent spatial types and their interconnections resulting in a cluster diagram for each plan (Fig. 1). The six spatial types are colour coded (in the online image) and juxtaposed to show both the degree of openness to surrounding spaces and the potential for flexible connectivity. All spaces that are, or can become, open to adjacent spaces are represented as translucent while closed spaces are opaque. The interpenetration or overlap of connected space types is represented by an overlap of translucent colours. Openable walls are represented by direct adjacency while a connecting doorway is a line.

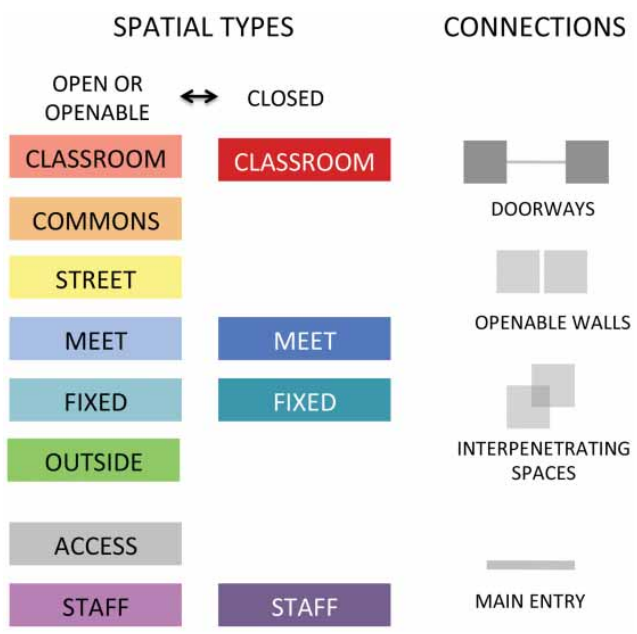

The diagrams produced from the plans are abstractions or conceptual tools designed to help understand the assemblage of spatial types. While this method seeks to be objective in establishing whether different spaces can or cannot be closed as evident on the plan, the method is intended to reveal rather than eliminate ambiguities. The sample of plans generates an enormous variety of diagrams and demonstrates that spatial innovation is moving in many directions at once with a great deal of experimentation. However, we suggest that these plans can be categorised within a framework of five cluster types along a loose continuum from the traditional corridor-based classroom plan to the fully open plan. These cluster types are demonstrated in figures 2-6 which first show a generic diagram followed by example plans that fall into that category and the specific diagrams derived by mapping them.
Figure 1. Types, connection \& diagrams. 
Figure 2. Type A: traditional classroom clusters.

\section{GENERIC DIAGRAM}

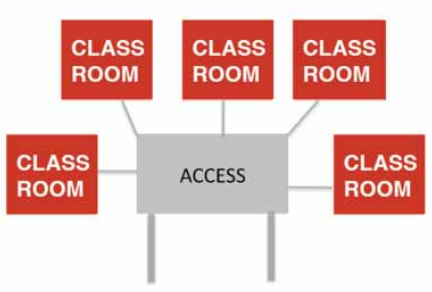

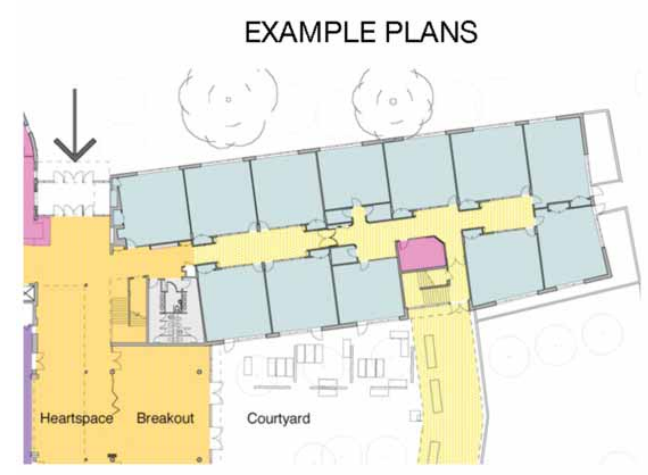

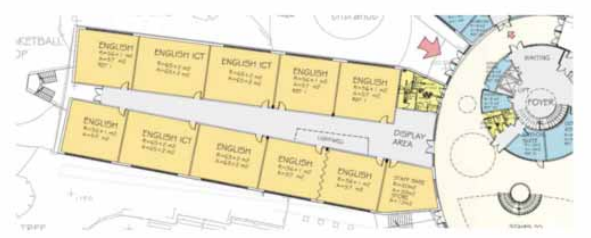

DIAGRAMS
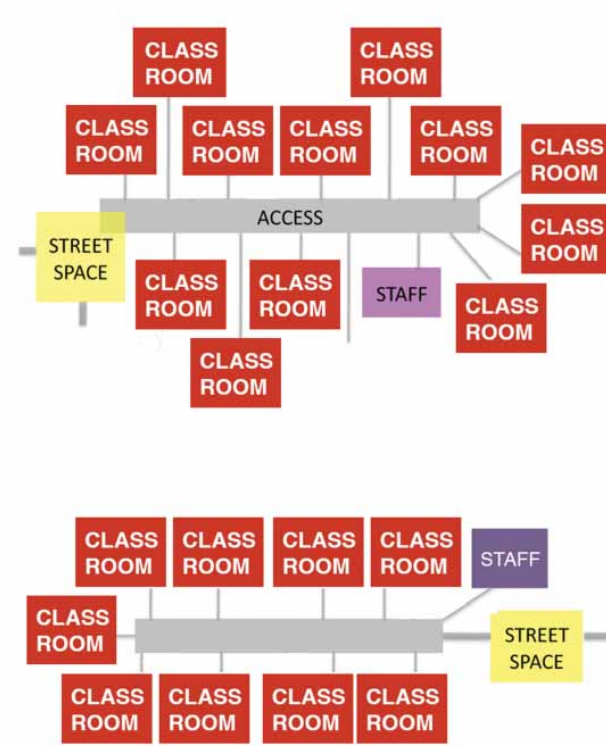

Whilst not all plans fit neatly into these five cluster types we suggest this can be a useful framework to analyse the range of spatial experimentation that is taking place in response to changing pedagogies.
Type A (Fig. 2) includes plans where clusters of traditional closed classrooms are entered from a corridor or access space without direct access to other teaching spaces and without openability between 


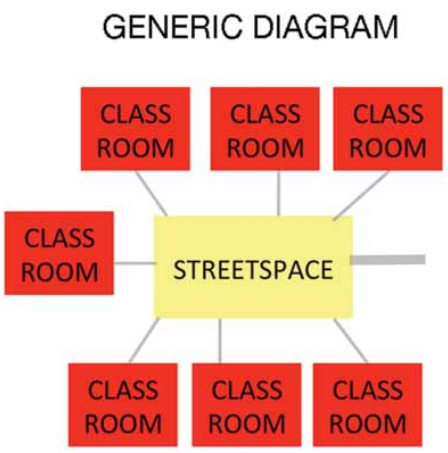

Figure 3. Type B:

traditional classrooms + streetspace.
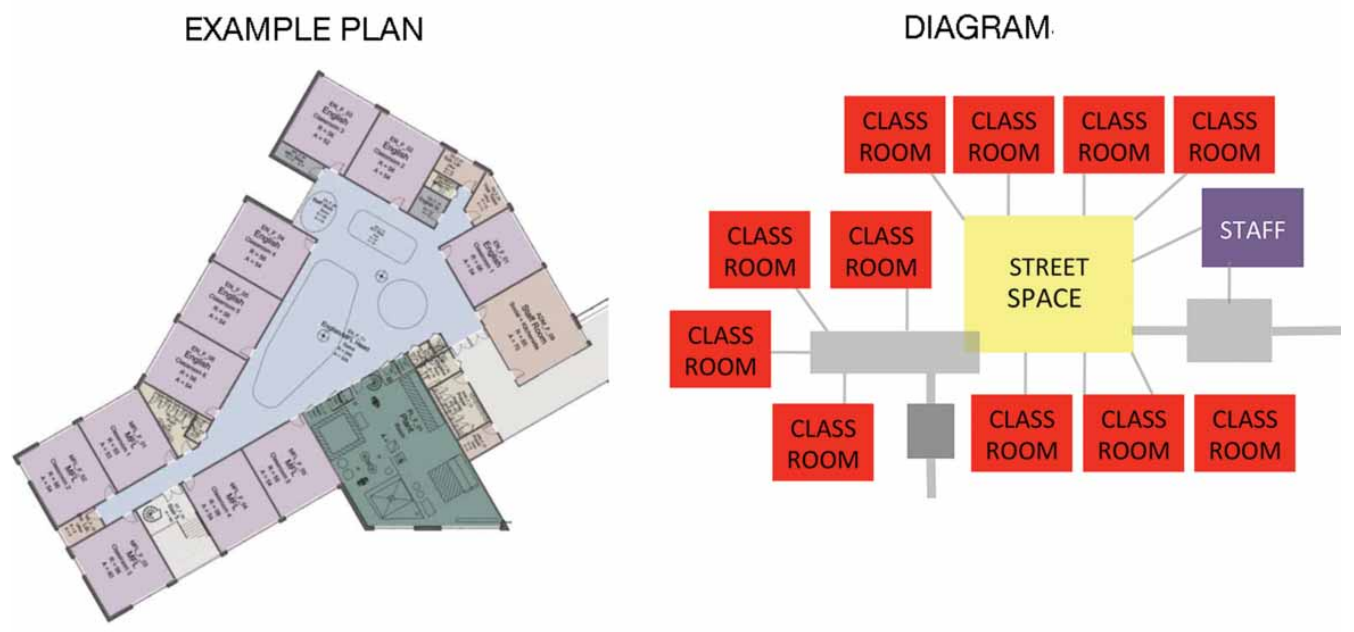

classrooms. While other spatial types (such as the

changing anything else: hence 'classrooms + street'streetspace' in Figure 2) may be provided for space'. This is an adaptation that introduces streetthe larger school they are not incorporated into space into the teaching/learning cluster while the learning cluster. Type B (Fig. 3) is identical to keeping the classroom cells intact but without any the first except that the corridor access to the classcommons or convertibility. Here we find a recognition rooms is expanded to become streetspace without of the value of a 'breakout' space but the classroom 
remains a closed cell that one must 'break' fromthere can be no easy flow between spaces.

Both of these types remain largely traditional in spatial structure. Since the sample of plans was chosen from those showcased by organisations promoting pedagogical change it is surprising to find that almost half of the sample $(44 \%)$ are of these types. In these plans architectural innovation often occurs at the level of the public spaces of the school rather than within the teaching clusters. Thus one might find 'learning streets', 'breakout' spaces and 'outdoor learning' environments but the primary learning environments (ie, the classrooms) are insulated from change. In such plans traditional classrooms dominate teaching/learning clusters while streetspace is created one level higher in the spatial assemblage. One interpretation here is that tensions between discipline and student-centred learning are resolved through an architecture that seems to provide both while retaining discipline at its core.

Type C (Fig. 4) we have called 'convertible classrooms' - these are learning clusters where flexible walls enable two or more traditional classrooms (and perhaps adjacent meeting and wet areas) to be converted into a single commons. Such plans enable a wider range of pedagogies while retaining reversibility to the traditional classroom. Type $D$, which we have termed 'convertible streetspace' (Fig. 5), includes plans where clusters of classrooms can be opened to streetspace as well as to each other to become a larger 'commons'. Again reversibility to the traditional classroom is retained. Degrees of openability between spaces vary but we have mapped them as open when more than about half of the party wall is openable. This type resembles
Type B ('classrooms + streetscape') but enables a far greater range of pedagogies because of the capacity to convert to commons with openable walls.

Type E (Fig. 6) we have called the 'dedicated commons' where a protected 'commons' comprises the spatial core of a learning cluster that cannot be converted to closed classrooms without major renovation. In this case there is no clear generic diagram although a fluid transition from streetspace to commons is generally apparent. This category incorporates a broad range of open plans that cannot be converted to traditional classrooms-more a collection of spatial innovations than a strict spatial type since it is largely defined by what it is not. Here the bridges to traditional pedagogy are burnt and doorways are largely abandoned. It is notable, however, that some such plans have added one or two traditional classrooms as closed presentation spaces attached to the streetspace or commons.

\section{Discussion}

We suggested earlier that our method is intended to reveal rather than to eliminate ambiguities and there are many variations that lie between and within the types diagrammed here. These are maps and not territories, they are conceptual structures we find useful rather than categories we have discovered. In one sense these five types can be regarded as two traditionals ( $A$ \& B), two convertibles $(C \& D)$ and the dedicated commons. The distinction between $A$ \& $B$ is important because the addition of streetspace produces what we might call a contemporary/traditional model connected to marketing and image. The distinction between $C \& D$ is between fundamentally different kinds of conversion. In the end 
GENERIC DIAGRAM \& CONVERSION

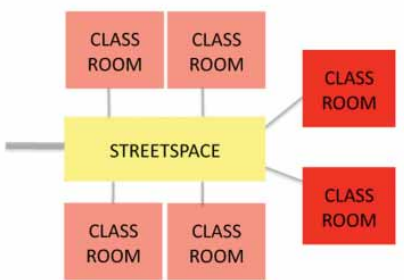

Figure 4. Type C:

convertible classrooms.
EXAMPLE PLANS
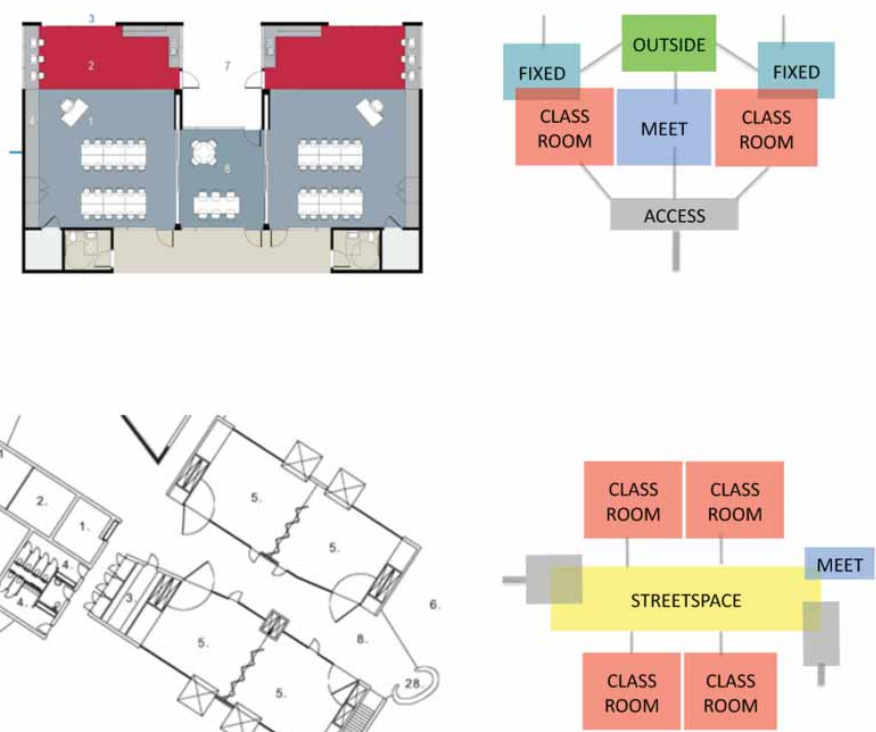

CONVERSIONS
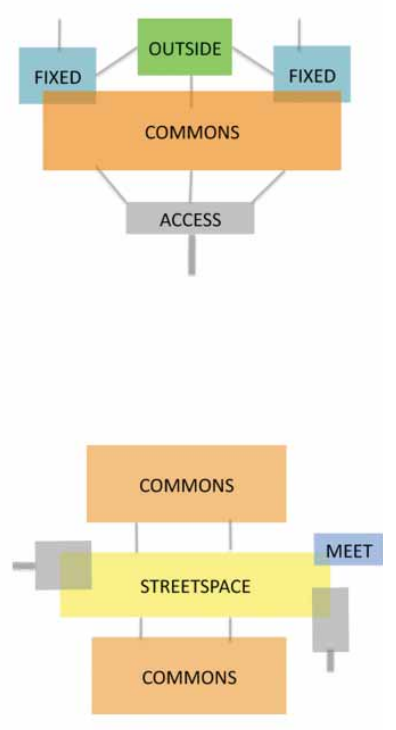

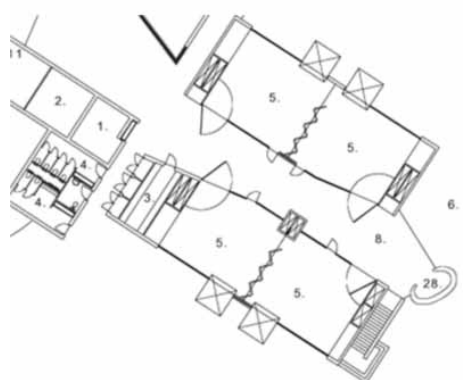

the simple typology becomes the means to understand the complexities of adaptation and assemblage. The question of adaptability has already been used, in part, to define these plan types but it is also linked to a much larger question about what adaptability or flexibility means: the capacity for change can refer to the architectural shell, to the furniture and loose parts within it, to the 
Figure 5. Type D:

convertible streetspace.
GENERIC DIAGRAM \& CONVERSION
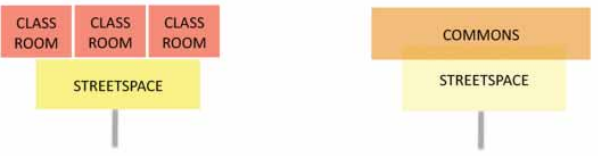

EXAMPLE PLANS

DIAGRAMS

CONVERSIONS
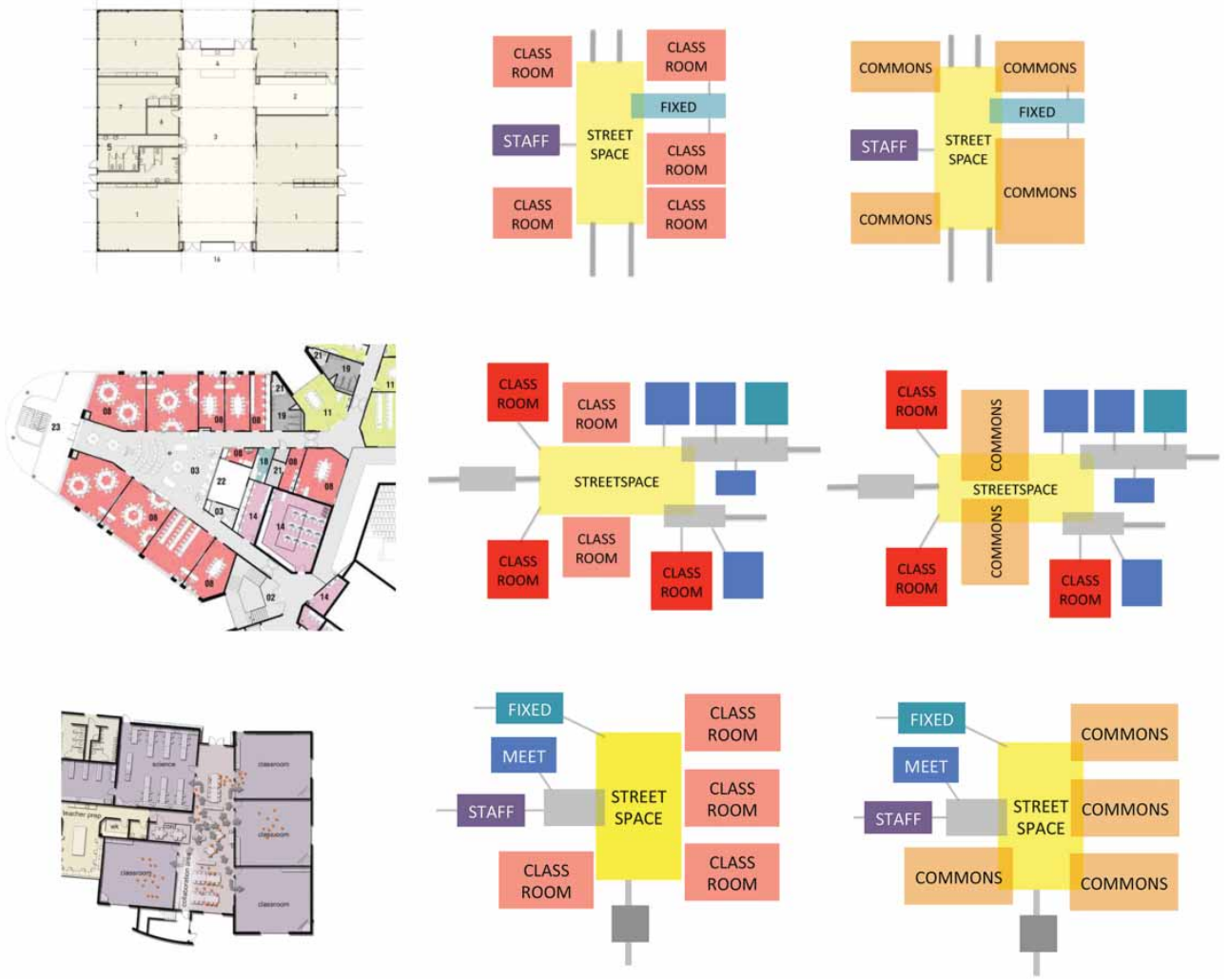
GENERIC DIAGRAM

$$
\begin{gathered}
\text { COMMONS COMMONS } \\
\text { STREETSPACE }
\end{gathered}
$$

EXAMPLE PLANS
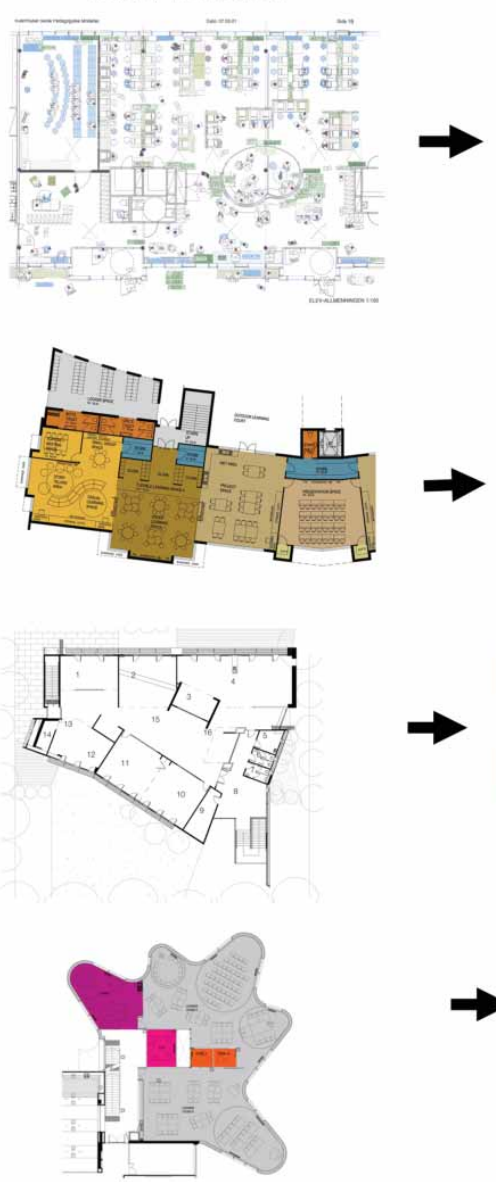

DIAGRAMS
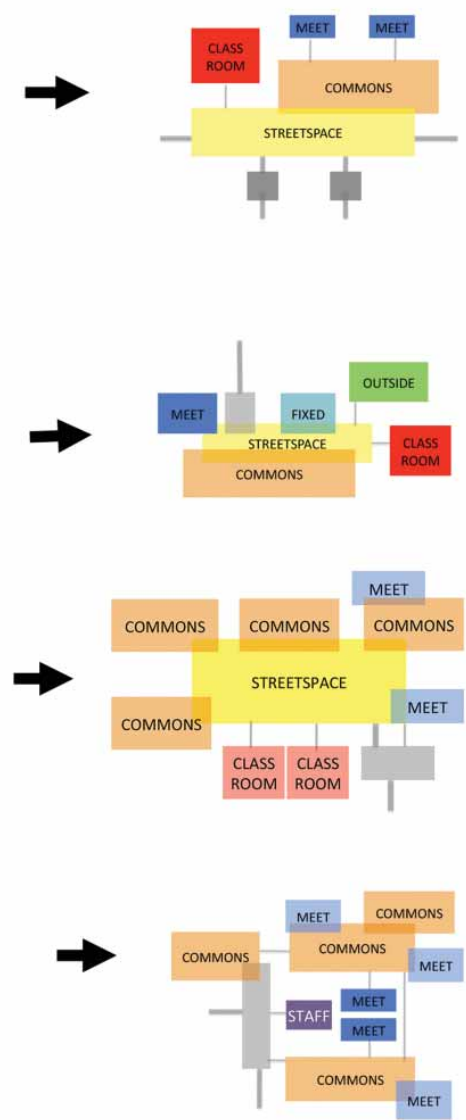

Figure 6. Type E: dedicated commons. 
people and their activities, and to the institutional regimes of control. ${ }^{26}$ Our analysis is limited to the flexibilities enabled by the architecture and it is crucial here to make a distinction between two kinds of flexibility. First is the reversible convertibility from traditional to constructivist pedagogies and back. Second is the ways the building enables flexible flows from one activity type to another within the constructivist pedagogy. These two kinds of adaptation-perhaps termed 'convertibility' and 'fluidity'-operate on different rhythms and at different scales of control. The rhythms of convertibility are much slower, often requiring walls and furniture to be moved, linked to changing pedagogical regimes.

The plan types we have labelled 'convertible' are those with a relatively high level of reversibility through the use of removable (folding, sliding) walls. These plans reflect the tension between pedagogies and the demand for an architecture that can satisfy both traditional and student-centred learning at different times. Convertibility links into higher levels of government and longer time cycles than everyday fluidity. The adaptation from classrooms to commons may not be possible during the course of a teaching session and may be controlled by principals rather than teachers or students. The traditional plans and dedicated commons are less adaptable in this sense than convertible types since the closed classroom constrains new pedagogies and the open plan constrains traditional teaching. Just as the classroom reproduces teacher-centred pedagogies, the irreversibility of the open plan can be construed as the use of architecture to coerce teachers into new pedagogies.
The second kind of adaptation-fluidity or perhaps 'agility'27-involves the capacity for flow and change between activities within the cluster. This is enabled in part by the scale and openness of the space, yet as the space becomes more exposed and noisy, as the classroom becomes 'commons' and then 'streetspace', it can constrain self-directed and reflective activities. In other words the openness also produces a demand for segmentarity, closure or semi-closure. One result is that many of the 'dedicated commons' type incorporate a variety of smaller segments to enable retreat: meeting rooms and alcoves but also presentation spaces. The most open of plans are often not the most adaptable because they constrain choice. In this sense fluidity is an adaptive condition produced by a conjunction of openness and closure rather than one or other end of this continuum. The more convertible and fluid types become more complex as different spaces are added to the cluster in a variety of spatial relationships (separation, openability, interpenetration). It is significant that there is no sense of convergence on any ideal architecture for the new pedagogies as there is for the old. While we have identified a simple generic diagram for the dedicated commons (see Figure 6 above), there is a great deal of experimentation and diversity. Some of these plans are simple barnlike spaces where success as a learning environment becomes a difficult matter of furniture arrangement and acoustics. Others are rendered more agile through the design of sliding walls. The danger is that open plans are cheaper to construct than segmented plans and can be supported for budgetary rather than pedagogical reasons. 
The distinction between 'streetspace' and 'commons' is difficult to draw clearly because common space so easily becomes streetspace when subject to cross-circulation. The significance of this distinction lies in the greater diversity of activities enabled in the commons, yet streetspace is far more prevalent in our sample plans than commons. One interpretation is that streetspace has become a visible face of progressive pedagogy and studentcentred learning, one that can be implemented while also preserving traditional practices. Streetspace also doubles as circulation space and is therefore easier to achieve within a strict budget when the demand for traditional classrooms must also be met. Plans of types A\&B are often celebrated as innovative because they introduce streetspace at the level of the school or as a classroom entry space, yet they supplement rather than transform traditional pedagogies and perhaps camouflage a lack of change.

Underlying this shift from teacher-centred to student-centred pedagogies is the issue of practices of power and how they are implicated in the architecture. Foucault's critique of disciplinary technology insists that space becomes implicit and complicit in the production of subjectivity; the panoptic regime involves a particular spatial structure, a supervisory gaze with experiential and behavioural outcomes. Foucault's work explains a great deal about the traditional classroom, and it also sows the seeds for understanding the architecture of student-centred pedagogies. What he termed the 'apparatus' or 'dispositif' of power became a primary source for theories of 'assemblage' where micro-practices of power are integrated with understandings of the ways productive self-organised assemblages emerge from dynamic interactions between parts. ${ }^{28}$ In this sense the movement from traditional to constructivist pedagogies and from closed classroom clusters to more open spatial assemblages can be seen to parallel the move from Foucaultian to Deleuzian conceptions and practices of power. While all schools are stabilised by hierarchical structures (the control of the principal, teacher, curriculum and timetable), student-centred learning is based primarily in horizontal rhizomic networks of connectivity. Assemblage theory is a constructionist account of socio-spatial relationships focusing on the ways in which heterogeneous parts are assembled into a provisional whole.

The traditional classroom cluster of Type A embodies an architecture of order and surveillance that erases blurring between spaces and assigns specific tasks to specific spatial segments. Deleuzian thinking stresses connectivity, flows of desire, processes of identity formation and becoming; the spatial aspect is found in 'smooth' spaces and rhizomic or networked spatial structures. This can be seen as a move from an assemblage of discipline to one of becoming; top-down practices of 'power over' make way for student-centred empowerment or 'power to'. ${ }^{29}$ Yet these new assemblages are also a site of new practices of 'power over' since many have a spatial segment designated as 'staff' incorporated into the learning cluster. Whereas the more traditional plans tend to exclude staff areas from the cluster, the more progressive plans are likely to incorporate them. While progressive pedagogies involve more collaboration of staff with students this co-location is also linked to issues of discipline and control. In many cases this is clearly a surveillance function and some plans locate the 
staff area with a panoptic view over common learning spaces. Contradictory desires both to enable student-centred learning and to maintain staff control can result in forms of camouflaged surveillance. On some plans panoptic locations are designed and named as 'resources' or 'co-ordination'; in others, rooms or alcoves are left blank in locations that could be appropriated for staff control. Staff often occupy an ambiguous zone on the edge of a cluster leaving the cluster as studentcentred. The transformation into an open plan raises concerns about discipline that are addressed by producing new forms of surveillance: one panoptic regime is replaced by another.

There is nothing surprising here; micro-practices of power are not eradicated, rather we move from regimes of discipline to those of control. ${ }^{30}$ A key question here is that of resilience - the capacity of a complex adaptive assemblage to remain dynamic and respond to change within the framework of a sustainable regime. ${ }^{31}$ The learning cluster must offer a resilient sense of place to be effective; not a capacity to bounce back to a stable state but rather a capacity to adapt to change without lurching into a new regime or descending into chaos. A key question lies in what kinds of plans have such resilience and remain open to new pedagogies. Conversely which of them are effectively constructed ideologies of 'openness as freedom' that will ossify or revert to traditional classrooms in time? The most resilient of the plans are those with a diversity of learning spaces and high levels of fluidity.

There can be no getting to the bottom of this because when highly adaptive learning environments work well they retain a certain mystery and magic that is both social and spatial. While the diagrams may look systematic and formulaic this is a misconception. The diagrams have two functions, one practical and one theoretical. The practical function we have demonstrated as best we can through the analysis: it is to identify the similarities that underlie what may appear to be radically different plans in a manner that can be seen at an abstract level that both designers and educators can understand. The level and kind of convertibility and fluidity/agility of school plans should be the subject of debate. We suggest that the diagrams can help to lift that debate from the specifics of particular plans, or ideologies of open versus closed, into a discourse of multiple plan types. For architects, who universally loathe being given template plans to copy, this leaves scope for both creative adaptation within plan types and the invention of new types.

The theoretical function of the generic diagrams is that they resonate with what Deleuze and Guattari call 'abstract machines'. ${ }^{32}$ We are dealing here with the immanent productive forces of assemblage, the ways that flows of desire congeal into certain socio-spatial patterns. The current plans mostly reveal contradictory desires for both traditional and student-centred pedagogies: desires for streetspace without deeper change and desires for convertibility evident in the first four types. We expect that in time the plans we identify as 'dedicated commons' will change the most as they are more responsive to pedagogical practice. In the end it is not theory that matters here but the use of theory as a conceptual tool for the critique of practice. The complex adaptive assemblage is a framework for re-thinking 
constructivist learning environments and the design of resilient schools.

We are not in a position to say which of these plans or pedagogies work: that is a question for detailed case study evaluation. Our goal is to deepen the level of engagement of both architects and educators with these issues. What we have demonstrated is that the range of plans seen as innovative from the perspective of progressive learning organisations is very broad, and that the 'openness' of such plans can be usefully conceived within a five-part typology. The typology loosely aligns with a continuum from 'traditional' closed classrooms, through a range of 'convertible' types to what we term the 'dedicated commons'. We have drawn some crucial distinctions that have not been made before and that we hope can enlarge the discourse of school design. The first is between two kinds of flexibility: the 'convertibility' (or 'reversibility') of plans from one pedagogy to another, versus the 'fluidity' (or 'agility') that plans enable between one spatial practice and another. Convertibility enables openness and closure-an architecture of reversible change. Fluidity is a property identified with the multiplicitous practices of student-centred pedagogies. The traditional plans embody an architecture of reproduction: sometimes under the camouflage of progressive streetspace. The convertible plans embody the tensions between traditional and constructivist pedagogies -and they may reproduce such tension. The plans classed as dedicated commons embody the burning of bridges: the architecture of a new order, or is it chaos? As openness increases, so does the demand for retreat spaces, new forms of closure and new regimes of control. This is an ongoing story — watch this space.

\section{Sources of the illustrations}

All the diagrams are by Kim Dovey.

Figure 1. The Diagrammatic Language: Types and Interconnections.

Figure 2. Sample plans from upper to lower: Minster School, UK, 2007 (Penoyre \& Prasad Architects); Radclyffe Secondary College, UK (Architects: ACP; image: British Council for School Environments).

Figure 3. Sample plan: Challney High School for Girls, UK (Architects: ACP; image: BCSE).

Figure 4. Sample plans from upper to lower: upper, Feather River Academy, USA, 2006 (Architects: Architecture for Education; image: designshare.com); lower, Canning Vale Middle School, Australia, 2004 (Architect: Hassell/Nitetta, Planner: Prakash Nair; image: CEFPI).

Figure 5. Sample plans from upper to lower: first, Botany Downs Secondary College, New Zealand, 2004 (ASC Architects; image: designshare.com); second, Havelock Academy, UK, 2012 (Architects: ACP; image: designshare.com); third, Alpine Middle School, Utah, USA, 2004 (VCBO Architecture; image: designshare.com).

Figure 6. Sample plans from upper to lower: first, Kvernhuset Secondary School, Norway, 2002 (Architects: Pir II Arkitektkontor AS); image: designshare. com); second, Baden Powell College, Australia, 2008 (Brand Architects; image: CEFPI); third, Dandenong Secondary College, Australia, 2011 (Hayball Architects; image: CEFPI); fourth, Fitzroy Secondary College, Australia, 2009 (McBride Charles Ryan Architects; image: CEFPI). 


\section{Notes and references}

1. This paper emerged from an Australian Research Council Linkage Project LP0776850 entitled 'Smart Green Schools'. We acknowledge the support and contributions of Clare Newton, Sue Wilks and Dominique Hes as collaborators, and Ben Cleveland and Ken Woodman as PhD students on this project.

2. M. Foucault, Discipline and Punish (New York, Vintage, 1979); M. Foucault, Power/Knowledge, C. Gordon, ed. (New York, Pantheon, 1980).

3. T. Markus, Buildings and Power (London, Routledge, 1993); C. Burke, I. Grosvenor, School: Iconic architecture (London, Reaktion, 2008).

4. J. Dewey. Democracy and Education (New York, Free Press, 1966;1916).

5. P. Blundell Jones, Hans Scharoun (London, Phaidon, 1995); H. Hertzberger, Space and Learning (Rotterdam, 010 Publishers, 2008).

6. J. Eccles, J. Jacobs, R. Harold, K. Yoon, A. Arbreton, C. Freedman-Doan, 'Parents and Gender-Role Socialization During the Middle Childhood and Adolescent Years', in, S. Oskamp, M. Costanzo, eds, Gender Issues in Contemporary Society (Newbury Park, Sage, 1993), pp. 59-83.

7. J. Bruner, Toward a Theory of Instruction (Cambridge, Mass., Harvard University Press, 1966); J. Piaget, Psychology and Epistemology (Harmondsworth, Penguin, 1972).

8. L. Vygotsky, Mind in Society (Cambridge Mass., Harvard University Press, 1978), p. 57.

9. D. Wood, J. Bruner, G. Ross, 'The role of tutoring in problem solving', Journal of Child Psychiatry and Psychology, 17(2) (1976), pp.89-100.

10. K. Fisher, 'Pedagogy and Architecture', Architecture Australia, 96 (5) (2007), pp.55-58.

11. <www.designshare.com/> Between 2001-2010 a total of 49 awards were given for completed new buildings in the middle-school category, for which data was available on the learning clusters of 41 .

12. <www.cefpi.org>

13. <www.bcse.uk.net> The British Council for School Environments did develop an awards programme with a similar agenda but without detailed plans. The BCSE became defunct in 2013 but the website continues.

14. M. DeLanda, A New Philosophy of Society (New York, Continuum, 2006); G. Deleuze, F. Guattari, A Thousand Plateaus (Minneapolis, University of Minnesota Press, 1987).

15. K. Dovey, Becoming Places (London, Routledge, 2010), Ch.2.

16. G. Deleuze, F. Guattari, A Thousand Plateaus, op. cit., pp.210-12.

17. L. Gunderson, C. Holling, eds, Panarchy (Washington, Island Press, 2002); B. Walker, D. Salt, Resilience Thinking (Washington DC, Island Press, 2006).

18. S. Johnson, Emergence (London, Penguin, 2001).

19. B. Davis, Inventions of Teaching: A Genealogy (Mahwah, Erlbaum, 2004); B. Davis, D. Sumara, Complexity and Education (Mahwah NJ, Lawrence Erlbaum, 2006); R. Upitis, 'School Architecture and Complexity', Complicity, 1 (1) (2004); R. Upitis, Raising a School (Yarker, Ont., Wintergreens Studio Press, 2010).

20. K. Dovey, 'Assembling Architecture', in, H. Frichot, S. Loo, eds, Deleuze and Architecture (Edinburgh, University of Edinburgh Press, 2013), pp.131-148.

21. L. March, P. Steadman, The Geometry of Environment (London, RIBA Publications, 1971).

22. B. Hillier, J. Hanson, The Social Logic of Space (Cambridge, Cambridge University Press, 1984); B. Hillier, Space is the Machine (Cambridge, Cambridge University Press, 1996).

23. T. Markus, Buildings and Power, op. cit.; M. Foucault, Discipline and Punish, op. cit. 
24. C. Alexander, S. Ishikawa, M. Silverstein, A Pattern Language (New York, OUP, 1977).

25. K. Dovey, Becoming Places (London, Routledge, 2010), p. 28.

26. S. Brand, How Buildings Learn (London, Penguin, 1995). We acknowledge the work of Ken Woodman in helping to rethink some of these meanings within his PhD dissertation: K. Woodman, 'Re-Placing Flexibility: An investigation into flexibility in learning spaces and learning' (PhD Dissertation, University of Melbourne, 2011).
27. S. Heppell, C. Chapman, R. Millwood, M. Constable, J. Furness, 'Building Learning Futures' (UK, Council for Architecture and the Built Environment, 2004).

28. M. Foucault, Power/Knowledge, op. cit., pp.194-228.

29. K. Dovey, Framing Places (London, Routledge, 2008; 2nd ed.), Ch.1.

30. G. Deleuze, 'Postscript on the Societies of Control', Negotiations, 59 (1992), pp. 3-7.

31. R. Upitis, Raising a School (2010), op. cit.; B. Walker, D. Salt, Resilience Thinking, op. cit.

32. G. Deleuze, F. Guattari, A Thousand Plateaus, op. cit., Ch.3. 